\title{
STATUS GIZI DENGAN PERKEMBANGAN ANAK USIA TODDLER
}

\author{
Lilis Maghfuroh \\ Program Studi S1 Keperawatan \\ STIKes Muhammadiyah Lamongan \\ E-mail : lilisahza99@,gmail.com
}

\begin{abstract}
In general, the process of each child's developmental stages is the same, that is the result of the maturation process. But in accomplishment, every child has a different speed. Based on the initial survey 5(50\%) children doubt in the development. The purpose of this study was to determine the relationship among nutritional status with the development of children age toddler. This research design using correlation analytical method with Cross Sectional approach. The number of 45 samples of children under five with simple random sampling technique with the independent variable of nutritional status and the dependent variable of development, analysis using Spearmen test with $\rho<0.05$. The test results obtained significant $0.002(\rho<0.05)$. Shows there is a relationship of nutritional status with the development of children age toddler. Mother's efforts to improve the development of toddler age children by improving nutritional status that includes 4 healthy 5 perfect in accordance with the needs of children aged toddler and provides stimulation of development through the provision of educational games and immediately bring the child to health personnel if there is suspected deviation of development.
\end{abstract}

Keywords: Nutrition Status, Development, Toddler

\begin{abstract}
Abstrak: Pada umumnya, proses tahapan perkembangan setiap anak sama, yaitu merupakan hasil dari proses pematangan. Tetapi dalam pencapaiannya, setiap anak memiliki kecepatan yang berbeda. Berdasarkan survey awal 5(50\%) anak meragukan dalam perkembangan. Tujuan penelitian ini adalah untuk mengetahui hubungan antara status gizi dengan perkembangan anak usia toddler .Desain penelitian ini menggunakan metode Analitik Korelasi dengan pendekatan Cross Sectional. Jumlah sampel 45 balita dengan teknik sampling simple random sampling dengan variabel independen status gizi dan variabel dependen perkembangan, analisis menggunakan menggunakan uji Spearmen dengan $\rho<0.05$. Hasil uji diperoleh nilai singnifikansi $0.002(\rho<0.05)$. Menunjukkan terdapat hubungan status gizi dengan perkembangan anak usia toddle. Upaya ibu untuk meningkatkan perkembangan anak usia toddler yaitu dengan meningkatkan status gizi yang meliputi 4 sehat 5 sempurna sesuai dengan kebutuhan anak usia toddler dan memberikan stimulasi perkembangan melalui pemberian permainan edukatif dan segera membawa anak ke tenaga kesehatan jika dicurigai ada penyimpangan perkembangan.
\end{abstract}

Kata Kunci : Status Gizi, Perkembangan, Anak Usia Toddler.

\section{PENDAHULUAN}

Perkembangan merupakan

bertambahnya struktur dan fungsi tubuh yang lebih kompleks dalam kemampuan gerak kasar, gerak halus, bahasa, serta sosialisasi dan kemandirian. Periode penting dalam masa perkembangan anak adalah masa balita. Perkembangan dasar yang berlangsung pada masa balita akan 
mempengaruhi dan menentukan perkembangan anak selanjutnya. Setelah lahir terutama pada 3 tahun pertama kehidupan, perkembangan sel-sel otak masih berlangsung dan terjadi perkembangan serabut-serabut syaraf dan cabang-cabangnya, sehingga terbentuk jaringan syaraf dan otak yang kompleks (Departemen Kesehatan RI, 2010).

Banyak negara yang mengalami berbagai masalah perkembangan anak seperti keterlambatan motorik, bahasa, perilaku, autisme, dan hiperaktif. Angka kejadian di Amerika Serikat bekisar 12-16\%, Thailand 24\%, Argentina 22\%, dan Indonesia 13-18\% (Alimul, 2008). Menurut UNICEF tahun 2010 di dapat data masih tingginya angka kejadian gangguan perkembangan anak usia balita (UNICEF, 2010).

Menurut WHO (World Health Organization) $5-25 \%$ dari anak mengalami gangguan motorik halus. Menurut Depkes RI, 2006 bahwa 16\% balita indonesia mengalami gangguan perkembangan, baik motorik halus dan kasar, gangguan pendengaran, kecerdasan kurang dan keterlambatan bicara. Ikatan Dokter Anak Indonesia (IDAI) jawa timur melakukan pemeriksaan terhadap 2.634 anak dari usia 0-72 bulan. Dari hasil pemeriksaan perkembangan ditemukan sebanyak $53 \%$ tidak normal, yaitu meragukan sebanyak $23 \%$, penyimpangan perkembangan sebanyak 30\%. Menurut penelitian yang dilakukan oleh Maghfuroh, L dan impartina, A 2014 didapatkan hampir setengah anak suspect dalam perkembangan bahasa,dan menurut Maghfuroh, L 2017 di TK sumurgenuk babat lamongan didapatkan 13 anak pengalami perkembangan motorik halus suspect dari 42 anak sedangkan penelitian yang dilakukan oleh Maghfuroh, L tahun 2017 di TK darma wanita kanor Bojonegoro 16 dari 44 anak pra sekolah didapatkan perkembangan motorik halus suspect.

Dari survey awal yang dilakukan oleh peneliti melalui wawancara dengan orang tua menggunakan KPSP didapatkan dari 10 anak terdapat $3(30 \%)$ anak mengalami perkembangan sesuai, 5(50\%) anak mengalami perkembangan meragukan, $2(20 \%)$ anak mengalami perkembangan penyimpangan, sehingga masih tingginya perkembangan anak toodler yang tidak sesuai.

Menurut (Soetjiningsih, 2013) faktor yang mempengaruhi perkembangan pada anak antara lain: Gizi ibu pada waktu hamil, gizi ibu yang buruk sebelum terjadi kehamilan, maupun pada waktu hamil lebih sering mendapatkan Bayi Berat Badan Lahir Rendah (BBLR), disamping itu dapat pula menyebabkan hambatan perkembangan otak janin yang mempengaruhi kecerdasan dan emosi.

Status Gizi, makanan memegang peranan penting dalam perkembangan anak, dimana kebutuhan anak berbeda dengan kebutuhan orang dewasa, status gizi yang kurang akan mempengaruhi kekuatan dan kemampuan motorik kasar anak. Perkembangan anak yang baik dipengaruhi oleh asupan gizi yang seimbang, baik kualitas maupun kuantitasnya, yang meliputi 4 sehat 5 sempurna (Widyastutik dan Widyani, 2010).

Stimulasi, merupakan hal yang penting dalam perkembangan anak. Anak yang mendapat stimulasi yang terarah dan teratur akan lebih cepat berkembang (Soetjiningsih, 2013).. 


\section{METODE}

Desain dalam penelitian ini adalah analitik korelasi dengan jenis rancangan Cross Sectional. Pada penelitian ini populasinya adalah Seluruh anak usia toddler di Dusun German Desa German Kecamatan Sugio Kabupaten dengan jumlah 50 balita dan Sampel pada penelitian ini adalah sebagian anak usia toddler di Dusun German Desa German Kecamatan Sugio Kabupaten Lamongan dengan jumlah 45 balita dengan teknik simple random sampling. Data penelitian ini diambil melelui Kuesioner Prascreening Perkembangan (KPSP) yang dibagikan kepada orang tua.

Pada penelitian ini uji yang digunakan adala Uji Spearmen dengan bantuan perangkat lunak komputer program Statistical Product and Service Solution (SPSS) 16.0 for windows dengan tingkat singnifikasi $\alpha$
$=0,05$. peneliti menggunakan subjek harus mendapatkan persetujuan dari subjek yang diteliti dan dari institusi tempat penelitian.

\section{HASIL DAN PEMBAHASAN \\ Hasil}

Karakteristik responden dalam penelitian ini meliputi umur anak,jenis kelamin anak, urutan kelahiran, umur orang tua, pendidikan dan pekerjaan orang tua. Berdasarkan tabel 1 karakteristik dari 45 responden yang diteliti sebagian besar anak berjenis kelamin perempuan sebanyak 25 balita atau 55,6\% , hampir sebagian anak urutan kelahiran pertama sebanyak 22 atau 48,9 \% , sebagian besar umur orang tua 26-35 tahun sebanyak 23 atau 48,9\%, hampir sebagian pendidikan orang tua SMA sebanyak 19 atau 42,2 \%, hampir sebagian pekerjaan orang tua sebagai IRT sebanyak 21 atau 46,7

Tabel 1.Karakteristik Responden

\begin{tabular}{lll}
\hline Karakteristik & Frekuensi & Prosentase (\%) \\
\hline Jenis kelamin & & \\
Laki-laki & 20 & 44,4 \\
Perempuan & 25 & 55,6 \\
Urutan kelahiran & & \\
1 & 22 & 48,9 \\
2 & 18 & 40 \\
$\mathbf{2}$ & 5 & 11,1 \\
Umur ortu & & \\
$18-25$ & 22 & 48,9 \\
26-35 & 23 & 51,1 \\
Pendidikan ortu & & \\
SD & 2 & 8,9 \\
SMP & 14 & 31,1 \\
SMA & 19 & 42,2 \\
PT & 8 & 17,8 \\
Pekerjaan Ortu & & \\
Wiraswasta & 20 & 44,4 \\
PNS & 2 & 8,9 \\
IRT & 21 & 46,7 \\
\hline
\end{tabular}


Tabel 2. Status gizi dan perkembangan anak

\begin{tabular}{ccccccccc}
\hline Status gizi & \multicolumn{4}{c}{ Perkembangan } & \multicolumn{2}{c}{ Total } \\
\cline { 2 - 10 } & \multicolumn{2}{c}{ Sesuai } & \multicolumn{1}{c}{ Meragukan } & penyimpangan & $\Sigma$ & $\%$ \\
Gizi kurang & $\Sigma$ & $\%$ & $\Sigma$ & $\%$ & $\Sigma$ & $\%$ & & \\
Gizi baik & 20 & 71,5 & 9 & 56,2 & 5 & 31,2 & 16 & 100 \\
Gizi lebih & 1 & 100 & 0 & 0 & & 25,0 & 28 & 100 \\
Total & 23 & 51,1 & 10 & 22,2 & 12 & 26,7 & 45 & 100 \\
Hasil Uji Spearmen & Rank $\mathbf{0 . 4 3 9}$ Z Hitung=2.926 & Z Tabel $\mathbf{0 . 4 9 8 4} \boldsymbol{\rho}=\mathbf{0 . 0 0 2}$ \\
\hline
\end{tabular}

Berdasarkan tabel di atas didapatkan dari 45 balita, sebagian besar balita mengalami status gizi baik sejumlah 28 balita, sebagian besar balita 23 balita atau $51,5 \%$ mengalami perkembangan sesuai. Sedangkan sebagian kecil 1 balita atau 100\% berstatus gizi lebih hampir seluruhnya mengalami perkembangan normal.

\section{Pembahasan}

Pada tabel 2 diatas bahwa sebagian besar gizi baik sebanyak 28 balita atau $62,2 \%$ dan sebagian kecil gizi lebih sebanyak 1 balita atau 2,2\%. Hal ini sesuai dengan penelitian yang dilakukan oleh Mariza, Y. Y., \& Kusumastuti, A. C. (2013) sebagian anak dengan gizi normal. Dan berdasarkan penelitian Sitoayu, L., Pertiwi, D. A., \& Mulyani, E. Y. (2017) didapatkan sebagian besar status gizi normal.

Berdasarkan tabel 2 diatas diketahui bahwa, dari balita yang mengalami gizi baik didapatkan hampir seluruhnya mengalami perkembangan sesuai.

Status gizi baik merupakan balita yang kebutuhan nutrisinya seimbang antara makanan yang masuk kedalam tubuh (nutrien input) dengan kebutuhan tubuh (nutrien output) akan gizi tersebut. Karena status gizi digunakan sebagai tolak ukur terhadap perkembangan anak, sehingga semakin baik status gizi anak maka semakin baik pula perkembangan anak tersebut.

Menurut Almatsier (2012) nutrisi yang masuk kedalam tubuh anak tidak hanya untuk memenuhi kebutuhan nutrisi saja tetapi juga digunakan untuk proses perkembangan anak dalam hal ini perkembangan motorik kasar karena perkembangan motorik kasar membutuhkan koordinasi gerak otot-otot besar dan untuk menggerakkan otot-otot tersebut perlu nutrisi yang seimbang yang sesuai dengan kebutuhan anak usia toddler.

Status gizi pada anak usia toddler dipengaruhi oleh beberapa faktor antara lain yaitu jenis kelamin balita, berdasarkan tabel 1 sebagian besar balita berjenis kelamin perempuan sebanyak 25 balita atau $55,6 \%$.

Kebanyakan anak laki-laki lebih banyak beraktifitas dari pada anak perempuan. Karena anak perempuan jika banyak beraktivitas lebih muda diarahkan dari pada anak laki-laki sehinggan energi yang terbuang pada anak laki-laki lebih banyak dari pada anak perempuan.

Menurut Supariasa (2008) diketahui bahwa massa otot balita perempuan lebih sedikit dari pada balita laki-laki dan balita perempuan lebih sedikit beraktivitas dari pada balita laki-laki,meskipun jumlah kebutuhan nutrisi antara balita perempuan dan balita laki-laki sama tetapi balita laki-laki lebih aktif 
dibandingkan dengan balita perempuan dalam aktivitasnya oleh sebab itu nutrisi yang masuk kedalam tubuh balita laki-laki dimetabolisme dalam otot menjadi energi yang dapat digunakan untuk beraktivitas lebih banyak oleh sebab itu kebanyakan balita laki-laki mengalami status gizi kurang. Sedangkan nutrisi yang masuk ke dalam tubuh balita perempuan dimetabolisme dan di simpan dalam bentuk lemak karena aktivitas perempuan yang lebih sedikit dan hal itu yang menyebabkan balita perempuan mengalami status gizi baik dari pada laki-laki.

Urutan kelahiran juga merupakan faktor status gizi baik, pada balita berdasarkan tabel 1 hampir sebagian balita urutan kelahiran pertama dengan jumlah 22 balita atau $48 \%$.Anak pertama biasanya sering dimanja oleh orang tuanya, apapun yang mereka inginkan akan dipenuhi oleh orang tuanya karena mereka beranggapan segalanya milik anaknya termasuk juga dalam pemberian makanan, mereka akan memberikan makanan kepada anaknya secara berlebihan karena dalam hal ini tidak ada pesaing atau anggota anak lain oleh sebab itu anak pertama banyak mengalami status gizi baik.

Menurut Sugiyono (2008) orang tua akan memanjakan anak pertamanya dan orang tua memberikan makanan kepada balita secara berlebihan.

Faktor yang mempengaruhi perkembangan anak usia toddler antara lain umur orang tua dapat mempengaruhi perkembangan anak usia toddler berdasarkan tabel diatas sebagian besar umur orang tua berusia antara umur 26-35 tahun sebanyak 23 atau $51,1 \%$.Sebagian besar umur ibu berusia antara 26-35 tahun atau dewasa awal dimana pada usia tersebut orang tua sangat mudah menyerap informasi tentang perkembangan anak baik dari orang lain maupun dari media informasi sehingga orang tua mampu memberikan pengarahan atau stimulus kepada anaknya tentang perkembangan anak.

Menurut Andriani (2012) umur orang tua dapat mempengaruhi perkembangan anak karena orang tua merupakan guru pertama bagi anaknya. Jika umur orang tua baru memasuki dewasa awal dimana dalam usia ini orang tua sangat mudah untuk memberikan stimulasi atau perlakuan baik kepada anaknya.

Pendidikan orang tua pada hal ini juga mampu mempengaruhi perkembangan anak usia toddler menurut tabel diatas hampir sebagian berjumlah 19 atau $42,2 \%$ orang tua balita berpendidikan SMA. Pendidikan SMA merupakan tingkat pendidikan yang cukup mereka tidak sulit untuk mendapatkan informasi dan tidak juga mudah dalam mendapatkan informasi tentang perkembangan. karena informasi tentang perkembangan anak tidak hanya didapatkan di pendidikan formal saja mereka juga mendapatkan informasi tentang perkembangan anak lewat media informasi ataupun dari orang lain. Menurut Prasetyaningrum, Y. I., Kertia, N., \& Gunawan, I. M. A. (2016) tidak ada perbedaan karakteristik subjek penelitian berdasarkan pendidikan orangtua.

Pekerjaan orang tua juga mampu mempengaruhi perkembangan pada anak usia toddler, berdasarkan tabel diatas dimana pekerjaan orang tua di Dusun German Desa German Kecamatan Sugio Kabupaten Lamongan hampir sebagian berjumlah 21 atau $46,7 \%$ pekerjaan orang tua balita sebagai ibu rumah tangga. 
Bekerja sebagai ibu rumah tangga merupakan pekerjaan yang baik karena mereka lebih banyak meluangkan waktu kepada anaknya karena tidak ada pembagian waktu ke kegiatan lainnya mereka hanya fokus kepada anaknya, mereka dapat memantau perkembangan anak dan juga memberikan stimulasi kepada anaknya secara langsung untuk dapat melakukan hal-hal baru guna meningkatkan perkembangan anak. Menurut Ngastiyah (2015), pekerjaan orang tua sebagai faktor eksternal untuk mendukung perkembangan anak, karena apabila orang tua bekerja diluar rumah dan jauh dari anak maka orang tua tidak mampu memenuhi setiap kebutuhan dan tidak mampu mengawasi setiap perkembangan anak.

Selain itu berdasarkan hasil uji statistik dengan menggunakan SPSS dan menggunakan uji Spearmen Rho didapatkan nilai Spearmen Rho 0.439 sehingga nilai $\mathrm{Z}$ hitungnya 2.926 dan $\mathrm{z}$ tabel 0.4744 dimana $Z$ hitung $>$ dari $Z$ tabel dan nilai signifikan $\rho=0.002$ dimana $\rho<0.05$ maka $\mathrm{H}_{0}$ ditolak dan $\mathrm{H}_{1}$ diterima, artinya terdapat hubungan antara Status Gizi dengan Perkembangan Anak Usia Toddler di Dusun German Desa German Kecamatan Sugio Kabupaten Lamongan oleh karena itu semakin baik status gizi balita semakin baik pula perkembangan anak usia Toddler.

Semakin baik gizi anak semakin baik juga perkembangan anak tersebut. Menurut Soetjiningsih (2013) makanan yang masuk pada anak usia toddler tidak hanya untuk memenuhi kebutuhan nutrisi saja tetapi juga untuk memenuhi kebutuhan energi untuk beraktivitas, perlu diketahui pada usia ini rasa ingin tahu tentang sesuatu sangat tinggi mereka akan lebih aktif mencari tahu bergerak kesana kemari untuk mendapatkan informasi oleh sebab itu perlu ditunjang dengan nutrisi yang baik dan seimbang sesuai dengan kebutuhan anak.

Menurut Almatsier (2012) status gizi baik sangat berpengaruh terhadap semua aspek perkembangan dimana anak yang berstatus gizi baik akan mengalami perkembangan sesuai dengan usia anak tersebut.

\section{SIMPULAN}

Penelitian ini menunjukkan bahwa terdapat hubungan status gizi dengan perkembangan anak toodler.

\section{DAFTAR PUSTAKA}

Adriana. (2012). Tumbuh Kembang dan Terapi Bermain pada Anak. Jakarta: Salemba Medika.

Alimul, A. 2008. Pengantar Ilmu Kesehatan Anak untuk Pendidikan Kebidanan. Salemba Medika. Jakarta.

Almatsier, S. (2012). prinsip Dasar Ilmu Gizi. Jakarta: Gramedia Pustaka Utama.

Departemen Kesehatan dan Departemen Sosial.2010. Gizi Seimbang Menuju Hidup Sehat Bagi Balita.Jakarta : Depkes dan Depsos.

Maghfuroh, L,.Impartina, A,. (2014). Peran Stimulasi Orang Tua Terhadap Perkembangan Bahasa Pada Anak Toddler. Surya jurnal media komunikasi ilmu kesehatan. Jilid 2 hal.58.

Maghfuroh, L, \& Putri, K. C. (2017). Pengaruh Finger Painting Terhadap Perkembangan Motorik Halus Anak Usia Prasekolah Di Tk Sartika I Sumurgenuk Kecamatan Babat Lamongan. Journal of Health Sciences, 10(1). 
Maghfuroh, L., \& Khotimah, N. (2017). Pengaruh Teknik Mozaik terhadap Perkembangan Motorik Halus Anak Prasekolah. Sain Med, 9(1), 5761.

Mariza, Y. Y., \& Kusumastuti, A. C. (2013). Hubungan antara kebiasaan sarapan dan kebiasaan jajan dengan status gizi anak sekolah dasar di Kecamatan Pedurungan Kota Semarang. Journal of Nutrition College, 2(1), 207-213.

Ngastiyah. 2015. Perawatan Anak

Sakit. Jakarta :Salemba Medika.

Prasetyaningrum, Y. I., Kertia, N., \& Gunawan, I. M. A. (2016). Status ketersediaan makanan dan status gizi ibu sebagai faktor risiko kegemukan pada anak prasekolah. Jurnal Gizi Klinik Indonesia, 13(2), 75-81.
Sitoayu, L., Pertiwi, D. A., \& Mulyani, E. Y. (2017). Kecukupan zat gizi makro, status gizi, stres, dan siklus menstruasi pada remaja. Jurnal Gizi Klinik Indonesia, 13(3), 121-128.

Soetjiningsih. (2013). Tumbuh Kembang Anak. Jakarta: EGC.

Supariasa. (2008). Penilaian Status Gizi. Jakarta: EGC.

Sugiyono, D. (2008). Metode Penelitian Bisnis. Bandung: Pusat Bahasa Depdiknas.

UNICEF, 2010. Angka Kejadian Pertumbuhan dan Perkembangan Anak Balita tahun 2010, tersedia dalam http://www.academia.edu. Diakses tanggal 20 Oktober 2016.

Widyastutik dan Widyani, 2010. Panduan Perkembangan Anak 0-1 tahun. Jakarta: Puspa Swara. 